\title{
The differential diagnosis of inflammatory joint disease in maternal-fetal microchimerism
}

\author{
Diagnóstico diferencial de doença inflamatória articular \\ em microquimerismo materno-fetal
}

Seme Youssef Reda'; Marina Lobato Martins ${ }^{2}$

\begin{abstract}
This study aimed at making the differential diagnosis of joint disease in a case of genetic chimerism in a female multiparous donor from the Regional Blood Bank of Guarapuava-PR (Hemocentro Regional de Guarapuava-PR), who had had three pregnancies of male fetuses. The patient showed joint pain prior to the last donation. It was possible to identify fetal cells remaining in circulation 20 years after her last pregnancy. Laboratory tests for acute phase proteins revealed possible termination of immune tolerance to circulating fetal cells. Thus, a hypothesis of graft-versus-host disease was formulated to explain the joint disease manifested by the donor.
\end{abstract}

Key words: hemotherapy service; chimera; pregnancies; triage; donor selection.

\section{INTRODUCTION}

In the medical area, the term chimerism is applied when cells from two different individuals merge into a single organism, originating an individual with two distinct cell types ${ }^{(5,6)}$. However, the term microchimerism is used when there is a low number of cells from an individual in the host. Pregnancy is an example of microchimerism due to the passage of fetal cells to the maternal circulation during gestation. Nevertheless, it is known that fetal cells may remain circulating for decades after delivery ${ }^{2}$ 7). Furthermore, conditions such as graft versus host disease in microchimeras have been widely reported ${ }^{(1)}$. Thus, in the present investigation it was possible to establish the differential diagnosis of acute phase disease in a donor from Hemocentro Regional de Guarapuava. Initially, the patient reported joint pain during the clinical trial and laboratory tests confirmed microchimerism. Therefore, the characterization of a case of microchimerism and the differential diagnosis of acute joint disease, hence defined as graft versus host disease, were established based on the initial report of joint pain during the clinical interview, which was prior to blood donation.

\section{METHOD}

1. Sample preparation for SRY genotyping and screening of acute phase proteins:

- The plasma sample for the identification analysis of fetal cells was collected from a triple blood bag for transfusion, specifically from the satellite plasma bag, containing SAGMannitol as anticoagulant. $400 \mu \mathrm{l}$ were removed from the satellite plasma bag and aliquoted into two eppendorf tubes, each containing $200 \mu \mathrm{l}$ of the sample. Subsequently, the tubes were stored in a freezer at $-80^{\circ} \mathrm{C}$.

- The total blood sample for acute phase protein analysis was collected after individual interview in order to inform the patient about the research that would be carried out. $5 \mathrm{ml}$ of blood in ethylenediaminetetraacetic acid (EDTA) were collected to assess acute phase proteins.

2. SRY genotyping

- In order to carry out SRY genotyping, the deoxyribonucleic acid (DNA) was isolated by using QIAamp DNA Blood kit (QIAGEN)

First submission on 18/05/12; last submission on 03/04/13; accepted for publication on 17/09/13; published on 20/12/13

1. PhD in Biotechnological Processes by Universidade Federal do Paraná (UFPR); biochemist and manager at the Production sector of Hemocentro regional de Grarapuava.

2. PhD in Biological Sciences by Universidade Federal de Minas Gerais (UFMG); biologist; chief manager of Technical-Scientific Development at Centro de Hematologia e

Hemoterapia de Minas Gerais. 
for the SRY gene and human albumin . The aliquots of isolated DNA were subjected to real time polymerase chain reaction (real time-PCR). We applied a TaqMan probe with a fluorophore and a quencher at the extremities in order to detect a specific sequence of the SRY gene from the short arm of the Y chromosome in the target DNA fragments amplified by polymerase chain reaction (PCR). As control, all extracts were also subjected to amplification of a fragment of human albumin.

3. The following laboratory exams were performed to assess acute phase proteins:

- antinuclear antibodies (ANA) byindirectimmunofluorescence using Hep2000 cells;

- rheumatoid factor (RF) by nephelometry;

- $\mathrm{C}$ reactive protein by nephelometry;

- erythrocyte sedimentation rate by Westergren.

4. The following exam was performed to determine previous contact with Streptococcus pyogenes:

- antistreptolysin 0 (ASLO) by nephelometry.

\section{CASE REPORT}

We report the case of a 49 year-old female patient, blood type 0 negative, multiparous with three full term pregnancies (all male fetuses), whose last pregnancy occurred 20 years ago. She was regarded as a regular donor at Hemocentro Regional de Guarapuava Regional Blood Center Guarapuava after 14 intermittent but continuous donations. Prior to the last donation, during the medical triage, she reported pain in her low back, right wrist and neck. Additionally, she confirmed she had been taking non-steroidal anti inflammatory drugs since the previous donation. Collection proceeded normally, but without the use of platelet concentrate (PC) and the frozen fresh plasma was separated for the blood products industry.

\section{DISCUSSION}

The case was analyzed by SRY genotyping due to the fact that it involved a regular donor who had never reported any complaints or symptoms prior to donations. Once the donor complained about joint pain during clinical triage, especially in the lower back, right wrist and neck, the possibility of graft-versus- host disease (GVHD), which is likely to occur in microchimeras, required further examination. Therefore, a preliminary protocol was established for the investigation into microchimerism. Tests for acute phase proteins were performed to assess the inflammatory process in progress and to exclude previous infection by Streptococcus pyogenes or autoimmune disease, which were followed by SRY genotyping. Table 1 shows laboratory test results.

TABLE 1 - Laboratory results for acute phase proteins and ASLO

\begin{tabular}{cl}
\hline Exams & \multicolumn{1}{c}{ Result } \\
\hline ANA & Nucleus NR* \\
& Nucleolus NR* \\
& Cytoplasm NR* \\
& Mitotic apparatus NR* \\
& Chromosome metaphase plate NR* \\
& $85 \mathrm{UI} / \mathrm{ml}(\mathrm{RV}:<250 \mathrm{UI} / \mathrm{ml})$ \\
ASLO & $33 \mathrm{UI} / \mathrm{ml}(\mathrm{RV}:<20 \mathrm{UI} / \mathrm{ml})$ \\
RF & $47 \mathrm{mg} / \mathrm{RV}:<6 \mathrm{mg} / \mathrm{l})$ \\
CRP & $35 \mathrm{~mm}(\mathrm{RV}: 0-20 \mathrm{~mm})$ \\
ESR &
\end{tabular}

ANA: antinuclear antibodies; ASLO: antistreptolysin 0; RF: rheumatoid factor; CRP: C-reactive protein; ESR: erythrocyte sedimentation rate; NR: non-reactive, $R V$ : reference value

One of the questions to be addressed was to confirm if the donor presented symptoms of rheumatoid arthritis caused by prior Streptococcus pyogenes infection. Table 1 shows that there was no infection by Streptococcus pyogenes, insofar as the result for ASLO remained within the reference values.

Additionally, it was necessary to exclude rheumatoid arthritis by ANA assay. This is essential in case of clinical suspicion of autoimmune diseases, particularly the group of collagen diseases such as systemic lupus erythematosus, autoimmune rheumatoid arthritis, etc. These autoantibodies may be deposited in different tissues and organs as well as fix complement, hence leading to inflammatory processes ${ }^{(5)}$. The possibility of autoimmune disease was excluded by ANA results (Table 1), inasmuch as they were not reagent.

Nevertheless, the results yielded for acute phase proteins, RF, C-reactive protein and erythrocyte sedimentation rate (ESR) showed changes in their final values "likely" indicating inflammatory process by graft versus host disease (GVHD) ${ }^{(3)}$. Subsequently, we proceeded to SRY genotyping by PCR, whose results are shown in Table 2.

TABLE 2 - Real time polymerase chain reaction results (real time-PCR - TaqMan) for human albumin and SRY

\begin{tabular}{ccc}
\hline TC & TC (PCR human albumin) & TC (PCR SRY) \\
\hline Result & 33.61 & 46.96 \\
\hline
\end{tabular}

TC: threshold cycles; PCR: polymerase chain reaction; real time-PCR: real time polymerase chain reaction 
DNA was extracted with the use of a QIAamp DNA Blood Kit (QIAGEN), in which the sample was amplified for human serum albumin, showing that there was free DNA recovery in the patient's plasma. Based on threshold cycles (TC), there was adequate DNA recovery and the sample was amplified with a high TC value in the PCR for the SRY gene. The amplification of human serum albumin presupposes recovery control of free DNA in the plasma, which does not distinguish maternal DNA from fetal DNA. As it is shown in Table 2, the occurrence of fetal DNA in the donor's circulation was evidenced, hence the diagnosis of maternal-fetal microchimerism was established.

In pregnancy, maternal exposure to fetal cells by cellular exchange between mother and son represents a unique immune event, inasmuch as the embryo is considered a semi-allogeneic graft. This occurs owing to the fact that half of the fetal cells have paternal genetic inheritance and, therefore, such cells are interpreted as allogeneic by the mother's organism. Accordingly, the maternal immune system must be able to tolerate the fetus cells so that there is no immunological rejection of the conceptus ${ }^{(7)}$.

Conversely, the exchange of cells between mother and child during pregnancy eventually becomes the foundation for the condition of maternal genetic chimerism. However, if the fetal cells remain in the maternal organism for a long period after the delivery, the maternal immune system can no longer tolerate them, initiating a process of rejection, which can clinically manifest as acute phase reactions and may feature some clinical similarities with autoimmune diseases such as collagen vascular diseases ${ }^{(1)}$.
Therefore, the joint inflammatory process that affected the studied patient was caused by the organic reaction to the fetal cells in her circulation, which after a given moment were no longer recognized by her immune system. To corroborate this hypothesis, specific laboratory tests were carried out and the result of positive genotyping for the SRY gene (Table 2) and acute phase proteins (Table 1) allowed us to conclude that it was a case of maternal-fetal microchimerism. Furthermore, the cause of the joint pain reported by the donor was the result of an organic reaction known as GVHD, probably due to the end of her maternal immune tolerance to the fetal cells from one or more of her children. Considering the fact that her last pregnancy occurred 20 years ago, allegedly these cells remained in her circulation for at least the same period until the onset of the first symptoms.

\section{CONCLUSIONS}

The use of a specific protocol and suitable analytical laboratory methods allowed us to define the cause of the clinical signs of joint inflammation reaction, which was characterized as GVHD. A rare case of maternal-fetal microchimerism in a multiparous donor was also confirmed. Accordingly, it was concluded that the transfusion services should establish specific protocols for multiparous donors in order to avoid the transfer of fetal cells to recipients of blood components. This could affect the GVHD recipient and also aggravate their clinical conditions.

\section{RESUMO}

Esse trabalho teve como objetivo fazer o diagnóstico diferencial de doença articular, em um caso de quimerismo genético de doadora multipara do Hemocentro Regional de Guarapuava-PR, com três gestações de fetos do sexo masculino, que apresentou dor articular previamente à última doação. Foi possivel identificar células fetais ainda presentes na sua circulação após 20 anos da última gestação. Os exames laboratoriais para proteinas de fase aguda demonstram possível término da imunotolerância às células fetais circulantes na doadora e, com isso, uma bipótese de doença de enxerto contra o bospedeiro foi elaborada para explicar a doença articular manifestada pela doadora.

Unitermos: serviço de hemoterapia; quimera; gestações; triagem; seleção do doador.

\section{REFERENCES}

1. BARCELLOS, K. S. A.; ANDRADE, L. E. C. Microquimerismo fetalmaterno nas doenças reumáticas autoimunes. Rev Bras Reumatol, v. 44, n. 1, p. 5361, 2004.
2. BIANCHI, D. W. et al. Male fetal progenitor cells persist in maternal blood for as long as 27 years postpartum. Proc Natl Acad Sci, v. 93, p. 705-8, 1996.

3. BILATE, A. M. B. Inflamação, citocinas, proteínas de fase aguda e implicações Terapêuticas. Temas de Reumatologia Clínica, v. 8, n. 2, p. 47-51, 2007. 
4. DUARTE, A. A. Fator antinúcleo na dermatologia. An Bras Dermatol, v. 80, n. 4, p. 387-94, 2005.

5. PEARSON, H. Human genetics: dual identities. Nature, v. 417, p. 1011, 2002.

6. QUIROS ALPIZAR, J. L.; ALPIZAR MIRANDA, K. E. Quimerismo genético um nuevo paradigma para la medicina legal. Med Leg Costa Rica, v. 26, n. 2, p. $7378,2009$.

7. SARAFANA, S. et al. Aspectos da imunologia da gravidez. Acta Med Port, n. 20 , p. $355-8,2007$. 